\title{
A Relação entre morte e retórica nos nos diálogos Górgias e Apologia de Sócrates
}

\author{
JULIA GALVANHO MYARA *
}

* Doutoranda em Filosofia pela PUC-Rio
RESUMO No diálogo Górgias, Sócrates não parece disposto a aceitar incondicionalmente a beleza, o poder e a grandeza da retórica, tampouco a sabedoria de Górgias. Ele coloca, através de seus elenkhoi, o valor da arte retórica em questão e assim, parece promover uma espécie de interdição contra a grandeza absoluta da retórica defendida pelos sofistas. Porém, em diversas outras obras de Platão, principalmente na Apologia de Sócrates, Sócrates emprega múltiplas vezes estratégias clássicas da retórica forense que, de muitos modos, pode ser aproximada da retórica do próprio Górgias. Dessa forma, não é ocioso perceber que a retórica aparenta possuir certa utilidade, tanto para o personagem Sócrates nas conversas com seus interlocutores, quanto para o autor Platão, no seu projeto político-pedagógico-filosófico. Dessa maneira, é importante lembrar que a boa utilidade da retórica em questão só poderia ser explorada plenamente enquanto submetida a valores filosóficos. Dessa forma, Sócrates mostra-se capaz de utilizar-se da arte retórica sem corromper-se ou tornar-se injusto e isso se dá, em última analise, devido à relação diferenciada que ele possui com a morte. No diálogo Górgias, fica evidente que Górgias, Polo e Cálicles parecem viver subordinados ao medo de serem acometido por injustiça (despojado se seus bens, exilados ou assassinados). Desse modo, o uso que fazem da retórica relaciona-se com uma manutenção ou conquista de poder para evitar sofrer injustiça ou ser subordinado à vontade do mais forte e isso os levaria, segundo a visão socrática, a cometer injustiça e buscar então tornar-se o mais forte. Dessa forma, adotar totalmente a retórica proposta pelos sofistas seria tornar-se injusto. Assim, ao não temer a morte, Sócrates pode adotar, com ressalvas, estratégias retóricas e permanecer sob o signo de virtude filosófica.

PALAVRAS-GHAVE Retórica; morte; justiça. 
O PRESENTE artigo busca explorar brevemente a relação entre morte e retórica na personagem Sócrates nos diálogos Górgias e Apologia de Sócrates ${ }^{1}$ na obra de Platão, de forma que seja apresentado um mapeamento preliminar da questão. Esse estudo também pretende sustentar uma leitura possível que afirma uma relação de Sócrates com a arte retórica cujo alicerce não é uma negação ou rejeição da mesma, como muitas vezes pode aparentar, mas, antes disso, essa relação se edifica, essencialmente, em uma apropriação seletiva e uma ressignificação promovida pelo próprio Sócrates (enquanto personagem de Platão).

Primeiramente, esse estudo apresentará as principais diferenças e semelhanças em relação à sobrevida da alma nos diálogos Górgias e Apologia de Sócrates. Em segundo lugar buscarei mostrar como Sócrates se relaciona com essa questão em ambos os diálogos. Em terceiro, será sustentada a tese que afirma que a relação diferenciada de Sócrates com a retórica clássica só é possível, pois ele possui diferentemente dos sofistas (Cálicles, Polo e Górgias), uma relação de libertação do medo da morte e a sobrevida ou não da alma.

É importante ter em mente uma diferença fundamental em relação à abordagem platônica da morte nos diálogos Górgias e Apologia. No Górgias, Sócrates encaminha o fim do diálogo apresentando um mito escatológico, mito este que a personagem, conforme o que ela própria diz, acredita ser verdadeiro. No segundo, apesar de haver certa “positividade” na maneira em que Sócrates parte para a morte, há um elemento de incerteza em relação à sobrevida e ao destino da alma. Incerteza que não desqualifica a confiança socrática em um elemento positivo da morte. Ambos os destinos parecem acertados, ambos são, de certa forma, positivos.

No diálogo Górgias, a conclusão do mito escatológico mostra que, caso a alma fosse justa, ela seria recompensada e nada teria a temer. Caso a alma fosse injusta, ela seria punida. A punição, levando em consideração tudo o que é dito sobre justiça e felicidade durante o diálogo, é algo bom, pois o homem é mais infeliz quando injusto e

1 A escolha do estudo dos diálogos Górgias e Apologia de Sócrates foi privilegiada pois ambos são essenciais para a compreensão da questão no recorte temático proposto e iluminam-se mutuamente. 
não punido. ${ }^{2}$ A personagem Sócrates, na tentativa de evidenciar ao sofista Cálicles a importância de uma vida orientada por ações justas, conta uma história que, segundo ele mesmo, pode até parecer um mito, porém, ele a considera um discurso sobre coisas verdadeiras ${ }^{3}$.

Sócrates conta para Cálicles (assim como Platão conta para os leitores de sua obra) que, antes dos deuses Olímpicos serem os senhores do mundo, nos tempos de Cronos, havia uma lei que concernia ao destino das almas dos homens, lei essa que, segundo Sócrates, ainda era vigente em seu tempo. Essa lei consistia em uma dinâmica de recompensa e punição para a alma dos homens. Aqueles que foram justos e pios, na morte iriam para a Ilha dos Venturosos (morada dos heróis e dos homens virtuosos). Lá eles seriam felizes, viveriam com seus semelhantes não experimentariam nenhum mal. Em contrapartida, aqueles que foram ímpios e injustos iriam para o Tártaro (morada dos Titãs e dos criminosos) onde seriam devidamente punidos por suas vidas injustas e ímpias.

O destino de cada homem não era apenas delimitado automaticamente a partir de suas ações em vida, mas eles também eram julgados, ainda em vida, por suas ações. E, a partir desse julgamento, eram encaminhados para a Ilha dos Venturosos ou para o Tártaro. Sócrates conta que, pelo motivo dos homens serem julgados no dia de sua morte, porém, ainda vivos e por juízes vivos, o destino da alma nem sempre era o correto e merecido. Os guardiões da Ilha dos Venturosos e o guardião do Tártaro dirigiram-se, então, a Zeus, que a essa altura já havia subido ao trono, e contaram que ambos os lugares estavam habitados por homens que não deveriam estar ali. Assim, Zeus decreta que a partir daquele momento, os homens seriam agora julgados nus e em morte por juízes também nus (filhos de Zeus), para que nenhum adorno ou motivo qualquer pudesse ocultar a verdade de suas vidas ${ }^{4}$.

Pode-se reparar que, segundo a perspectiva socrática, a morte não parece ser um fim ou uma aniquilação, mas simplesmente a separação que a alma sofre do corpo ${ }^{5}$ A alma, mesmo separada do corpo, conservaria em si as características que concernem

\footnotetext{
2 Mais adiante na pesquisa trabalharei essa "escala" de felicidade segundo a concepção socrática.

3 PLATÃO, Górgias, 523a.

4 PLATÃO, Górgias, 223a-224b.

5 PLATÃO, Górgias, $524 \mathrm{~b} 3$.
} 
a sua natureza, as marcas das suas ações em vida, e assim, o julgamento justo seria possível. As almas não virtuosas seriam encaminhadas para sua justa punição, que seria o único meio possível para se purgarem das injustiças cometidas, e as almas virtuosas, por sua vez, iriam receber suas justas recompensas por suas vidas retas ${ }^{6}$.

Parece que, a intenção socrática, ao contar o mito de pós-morte, mais do que mostrar o destino da alma dos justos e injustos, é influenciar seus ouvintes (ou leitores, no caso de Platão) a levarem uma vida mais justa através do incentivo pela dinâmica de recompensa e punição apresentadas. Após uma longa discussão sobre a importância da ação virtuosa e justa com Cálicles e Polo ter aparentemente ${ }^{7}$ falhado, o medo da punição levaria, mesmo que não idealmente, seu ouvinte a buscar levar uma vida mais justa e virtuosa, assim como o desejo pela recompensa no pós-morte.

Já na Apologia, caso a alma tenha o destino que a tradição lhe atribui, também nada o homem justo tem a temer. E, caso a alma vá para um longo descanso, um sono sem sonhos, novamente nenhum homem, justo, e dessa vez também o injusto, precisa ter medo. Ou seja, na Apologia, Sócrates desconsidera a certeza dessa sobrevida que aparece de maneira tão clara do diálogo Górgias. Ele explicitamente leva em consideração duas hipóteses: de a alma sobreviver e de a alma não sobreviver inserindo assim um elemento de incerteza ausente no Górgias.

Na Apologia, Sócrates fala que os homens julgam a morte um grande mal, e dessa maneira julgam serem sábios sem o serem, pois, de fato, desconhecem o que se passa na morte. A crítica socrática nesse momento não só concerne ao entendimento ordinário que seus conterrâneos possuem a respeito da morte, mas, também, a uma convicção que os homens têm de determinados assuntos que julgam terem conhecimento sem na verdade o terem. Ou seja, novamente podemos observar a insistência socrática de desvelar a ignorância real que se esconde por trás de um conhecimento ilusório e, de certa forma, arrogante.

Fora por demais grave, atenienses, meu procedimento, se, tendo permanecido no lugar indicado pelos generais eleitos por vós mesmos para comandar-me, em Potideia, Anfpipolis e Délio, arriscando-me, como qualquer outro, a morrer:

6 Não tratarei das almas incuráveis nesse momento da pesquisa.

7 Existe uma leitura que afirma que, apesar da conversa entre Cálicles e Sócrates aparentar um fracasso, há uma espécie de persuasão do personagem Górgias para a vida filosófica. 
vendo-me, agora, no posto em que me colocou a divindade, conforme creio e admiti, para dedicar-me exclusivamente à filosofia e examinar a mim e aos outros, só de medo da morte ou do que quer que seja viesse a desertar. Isto, sim, fora gravíssimo, e com todo o direito qualquer pessoa poderia processar-me por eu não acreditar nos deuses, uma vez que desobedecera ao oráculo, revelara medo da morte, senhores, outra coisa não é senão considerar-se sábio; equivale a imaginar alguém que sabe o que ignora. Ninguém sabe o que seja a morte, e, ignorando até mesmo se porventura não será para os homens o maior dos bens, temem-na como se soubessem com certeza que é o maior dos males. ${ }^{8}$

A partir daí Sócrates começa uma investigação a respeito da positividade da morte e, analisando as duas possibilidades de pós-morte, chega à conclusão que a morte é, na verdade, um bem e que julgar a morte um mal é ser um ignorante que se passa por sábio. Dessa maneira, ele espelha uma das acusações que sofre de volta ao seu júri e acusadores, pois estes, ao julgarem a condenação à morte uma punição, passam-se por sábios sem o serem.

A primeira possibilidade que o filósofo investiga é a de a morte ser como um grande e tranquilo sono sem pesadelos nem sonhos, onde, se for o caso, segundo ele, não pode ser ruim e, além disso, pode até ser desejável. Sócrates compara uma noite de sono reparador sem sonhos como, possivelmente, um dos momentos mais agradáveis da vida de qualquer um e julga esse destino de maneira positiva. Pode-se ver a seguir o raciocino socrático em relação a essa possibilidade:

Consideremos também quantas razões temos para esperar que a morte seja um bem. Morrer é uma de duas coisas: ou quem morre nada é e carece da menor sensação seja do que for, ou então, como se diz, é uma mudança e a passagem da alma deste lugar para outro. Se se tratar, de fato, da privação total de sensação, como no sono, quando quem dorme não é perturbado nem pelos sonhos: terá de ser a morte um ganho maravilhoso. No meu modo de ver, se escolhesse alguém uma noite como essa, de sono tranquilo que nenhum sonho perturbasse e a comparasse com as outras noites e os outros dias de sua vida, para decidir, depois de madura reflexão, quantas noites e quantos dias ele tivera em toda sua vida mais agradáveis do que aquela: não direi um simples particular, mas ate mesmo o Grande Rei acharia mais fácil de contá-las, em confronto com os outros dias e as outras noites. Se a morte

8 PLATÃO, Apologia de Sócrates, 28e 29b. 
for isso, considero-a um grande lucro. Porque todo o tempo não parecerá dessa maneira mais longo do que uma única noite. ${ }^{9}$

A segunda sugestão que Sócrates apresenta é a possibilidade da sobrevida da alma no Hades. Ou seja, a alma consciente e individuada encontraria com os verdadeiros juízes e com outras almas e receberia o tratamento adequado em relação a sua conduta em vida. Sendo a alma devidamente retribuída pelo que fez, ou seja, sendo tratada com justiça, nada o homem justo tem a temer, e pelo contrário, a morte seria um grande bem. Conforme o próprio Sócrates diz, esse destino da alma na morte seria tão bom que, se verdadeiro, é preferível morrer “mil vezes” e sofrer esse destino a permanecer vivo.

Por outro lado, se for a morte o trânsito daqui para um lugar diferente, sendo certo, como se diz, que todos os mortos lá se reúnem: que maior bem poderá haver, senhores juízes? Se ao chegar no Hades, livre dos que se dizem juízes, e lá encontrar os juízes verdadeiros, conforme contam, a distribuir justiça: Minos e Radamanto, e Éaco e Triptólemo, e tantos outros semideuses que foram justos durante a vida: seria má essa mudança? Ou passar a conviver com Orfeu, e Museu, e Hesíodo, e Homero: quanto não pagaríeis para alcançar tão grande ventura? Eu, pelo menos, desejo morrer mil vezes, se tudo isso for verdade. ${ }^{10}$

Porém, dentre todas as passagens que podemos observar na Apologia a respeito dos mitos e perspectivas da sobrevivência da alma e da vida no pós-morte, há uma que se mostra esclarecedora em relação à compreensão da verdadeira intenção de Sócrates com seu discurso. Essa intenção parece ser em ultima analise a impossibilidade de algo de ruim acontecer a um homem virtuoso e, dessa maneira, uma exortação da vida virtuosa. Pode-se observar a fé absoluta de Sócrates na impossibilidade que um homem justo tem de sofrer algum mal real. Essa crença que Sócrates tem sobre a impossibilidade do mal, não parece vir estritamente de uma relação com a divindade ou a religião grega clássica, apesar deste aspecto não poder ser desconsiderado, mas antes disso, parece que Sócrates valoriza, muito antes da vida em si, a vida justa e por isso, a morte não seria algo realmente terrível, visto que verdadeiramente terrível seria ser injusto.

9 PLATÃO, Apologia de Sócrates, 40e-41b.

10 PLATÃO, Apologia de Sócrates, $40 \mathrm{O} 41 \mathrm{~b}$. 
Também vós, juízes, deveis como eu ter esperança na morte e tomar consciência desta verdade, que nenhum mal pode acontecer a um homem de bem, nem em vida, nem depois da morte, que nunca os deuses se desinteressariam de sua sorte. ${ }^{11}$

Pode-se compreender então que, a morte, não entendida como um mal, não precisa ser evitada a qualquer custo. Um homem vivendo sob o medo da morte não poderia ser justo, pois suas ações estariam sempre orientadas pelo objetivo maior de não morrer. Sócrates, liberto do medo da morte não corre o perigo de tornar-se injusto ao evitá-la. Como é sabido, o resultado do julgamento de Sócrates é desfavorável e este é condenado à morte. É muito comum então que, por esse ponto de vista, Sócrates seja aproximado da figura do herói trágico. No entanto, como lembra Daniel Lopes no seu estudo sobre o diálogo Górgias, Sócrates se recusa a desempenhar o papel de herói trágico em seu julgamento.

Mas como a personagem Sócrates se constrói como um herói antitrágico no Górgias, em oposição à perspectiva de Cálicles e, por conseguinte, à do senso comum? A diferença em relação ao herói trágico reside, sobretudo, na forma como Sócrates se comporta perante a morte vaticinada por Cálicles, fundamentada na compreensão, diferente da de seu interlocutor, do que é o bem e o mal para o homem. Sócrates já havia demonstrado a Polo que cometer injustiça é tanto pior quanto mais vergonhoso do que sofrê-la, e que o segundo maior mal é cometer injustiça, na medida em que o maior mal é cometê-la mas não pagar a justa pena (479c-d). Essas convicções morais que Sócrates estipula como verdade moral, ancorada no fato de jamais terem sido refutadas por qualquer interlocutor que pensasse o contrário $(527 \mathrm{~b}-\mathrm{c})$, redimensiona, portanto, o que é verdadeiramente o bem e o mal: o "infortúnio" do homem não é a morte em si, por mais ignominiosa que ela possa ser (como seria a de Sócrates, segundo o vaticínio de Cálicles), mas a vida vivida de forma injusta; nesse sentido, a preocupação precípua do homem, se ele pretende ser feliz, não é viver o quanto mais e buscar todos os meios possíveis para garantir uma vida longeva independentemente da justiça (essa seria uma das "pseudoutilidades" da retórica aduladora, e, em específico, da retórica judiciária, cf. 511d-513c) mas viver, o tempo que for, de forma justa. ${ }^{12}$

11 PLATÃO, Apologia de Sócrates, 41c-d.

12 LOPES, A tragédia no diálogo: o caso Cálicles. In: PLATÃO. Górgias. Tradução do grego, ensaio introdutório e notas de Daniel R.N Lopes. São Paulo: Perspectiva, 2014, p. 100. 
O desfecho da morte de Sócrates oscila entre o aspecto despreocupado na maneira com que Sócrates lida com a possibilidade da própria morte e a realidade de sua condenação. Um aspecto essencial a ser notado no texto, como comentado anteriormente, é a maneira com que Sócrates parece não atribuir tanta importância à questão da morte, tampouco busca evitá-la a qualquer custo ou considerá-la um grande infortúnio ${ }^{13}$. Pelo contrário, Sócrates deixa evidente que a morte não deve ser temida, desconsiderando a existência ou não de uma sobrevida da alma. Para o filósofo, a possibilidade de cometer uma ação injusta é muito mais séria e terrível do que a possibilidade de morrer ${ }^{14}$.

Assim, a condenação à morte de fato não pode ser um desfecho trágico segundo os olhos do próprio Sócrates. Para ele, não é possível que algo de ruim aconteça a um homem justo ${ }^{15}$. Com essa afirmação pode-se reparar uma presença forte do princípio de autarquia socrática. Ou seja, uma autonomia frente à fortuna e aos acontecimentos exteriores à ação dele mesmo. Sócrates, mesmo condenado à morte, por ter permanecido sendo um homem justo até o fim, permanece sendo eudaimônico e as circunstâncias externas a ele mesmo não podem alterar este fato. A morte, não sendo considerada algo a ser temido nem algo que determina as ações do ser vivente, liberta o homem das ações condicionadas a esse evento.

No Górgias, que é um diálogo que questiona a função da arte retórica, há, desde o inicio, certo vinculo entre e relação da retórica com a morte. Os sofistas Polo, Cálicles e Górgias, em momentos diversos do texto e com suas diferentes personalidades, afirmam que o poder da arte retórica consiste em livrar aquele que é detentor de tal poder das contingências da vida. Ou seja, aquele que é um bom orador e fluente na arte da persuasão, pode livrar-se de acusações injustas que poderiam levá-los à falência, exílio, desonra e até a morte. Além disso, o rétor habilidoso poderia também, através de sua arte, exercer domínio sobre os homens, visto que possuem discursos que produzem efeitos quase encantatórios da alma de seus ouvintes ou interlocutores.

13 Isto será desenvolvido em outros contextos como o exercício para a morte.

14 Neste momento pode-se, novamente, estabelecer uma relação sobre o conceito de justiça entre a Apologia de Sócrates de Platão e a obra “Apologia de Palamedes” de Górgias (38b-c).

15 PLATÃO, Apologia de Sócrates, 30c-e. 
Parece que, a preocupação fundamental que orienta as ações dos sofistas citados e justificam a importância e grandeza da arte retórica é, além de obter poder para ser senhor dos outros homens, também obter poder para ser senhor do próprio destino e livrar-se da morte caso se encontre em alguma situação ameaçadora nesse sentido. Ou seja, o páthos que orienta o modo de vida dos sofistas parece ser o medo, que por sua vez só pode ser superado através da dominação dos outros homens.

Não é ocioso perceber como o discurso e a atitude socrática, tanto no Górgias, quanto na Apologia, invertem essa relação com a morte, o pós-morte e os discursos. Na Apologia de Sócrates fica claro para qualquer leitor, que Sócrates não parece muito preocupado com a perspectiva iminente de morrer. São muitas as passagens onde podemos observar esse elemento tão marcante.

Talvez alguém me objete: não te envergonhas, Sócrates, de teres adotado um gênero de vida que hoje poderá acarretar-te a morte? Ao que eu daria esta resposta justa: está enganado, amigo, se imaginas que, por menos que valha uma pessoa, deve pensar em morrer ou viver, em vez de considerar apenas se procedeu com justiça ou injustamente em todos os seus atos e se se comportou como homem de bem ou como celerado. ${ }^{16}$

O trecho acima parece ser, não por coincidência, resposta a uma passagem significativa da fala de Cálicles dirigida a Sócrates, no diálogo Górgias.

Aliás, caro Sócrates - e não te irrites comigo, pois falar-te-ei com benevolência -, não te parece vergonhoso esse comportamento que, julgo eu, tu possuis e todos os outros que se mantêm engajados na filosofia por longo tempo? Pois se hoje alguém te capturasse, ou qualquer outro homem de tua estirpe, e te encarcerasse sob a alegação de que cometestes injustiça, ainda que não a tenhas cometido, sabes que não terias o que fazer contigo mesmo, mas ficarias turvado e boquiaberto sem ter o que dizer; quando chegasses ao tribunal, diante de um acusador extremamente mísero e desprezível, tu morrerias, caso ele te quisesse estipular a pena de morte. Ademais, como isto pode ser sábio, Sócrates, "que a arte, apossando-se de um homem de ótima natureza, torna-o pior”, incapaz de socorrer a si mesmo, de salvar a si mesmo ou qualquer outra pessoa dos riscos mais extremos, despojado pelos inimigos de todos os seus bens e vivendo abso-

16 PLATÃO, Apologia de Sócrates, 28b-c. 
lutamente desonrado na cidade? Para ser ainda mais rude, qualquer um poderia rachar a têmpora de um homem como esse sem pagar a justa pena. ${ }^{17}$

Há uma inversão real de valores presente na figura de Sócrates. O homem grego que fosse contemporâneo a ele possivelmente alimentava certos valores da vida cotidiana que Sócrates inverte em diversos sentidos. Nessa hierarquia de valores que envolvem acontecimentos contingentes, ações deliberadas, conquistas políticas, sociais e morais, desfortunas, desonras e falta de poder, Sócrates propõe transformações que pareceram muitas vezes estranhas. Para Sócrates, os valores que orientavam suas decisões estavam diretamente ligados com a ideia de felicidade ou eudaimonia. Porém, para o filósofo, felicidade não era ter poder e domínio sobre os outros homens, mas ter poder sobre si mesmo, e assim, nessa autarquia, ter uma vida justa e não sucumbir ao medo da morte que, potencialmente, o levaria a agir de maneira não justa a fim de evitá-la.

Contudo, o meu argumento, que já foi dito inúmeras vezes, embora nada o impeça de ser repetido, é este: eu afirmo, Cálicles, que o mais vergonhoso não é ter a têmpora rachada injustamente, ou ter a minha bolsa ou o meu corpo lacerados, mas é pior e mais vergonhoso rachar a minha têmpora e lacerar as minhas propriedades injustamente, ou roubar-me, escravizar-me, violar a minha casa; em suma, qualquer que seja a injustiça cometida contra mim ou contra minhas propriedades, é pior e mais vergonhoso para quem comete injustiça do que para mim que a sofro. ${ }^{18}$

Sócrates afirma que o homem mais feliz é o homem mais virtuoso e justo, e que as contingências (eventualmente maléficas) que ele pode sofrer nada se comparam ao sofrimento a que um homem injusto está submetido, devido às suas próprias ações. É evidente uma inversão da hierarquia do que deve ser priorizado na vida e de com que finalidade o homem deve orientar suas ações. Pode-se observar no trecho abaixo, uma passagem que apresenta essa hierarquia eudaimônica socrática.

$\mathrm{Eu}$, portanto, coloco mais uma vez as coisas nestes termos, e se as coisas forem assim e a injustiça for o mal supremo para quem a comete, ou se houver a possibilidade de um mal ainda maior do que esse mal supremo, ou seja, não pagar a justa pena uma vez cometida a injustiça, que tipo de socorro seria esse que tornaria o homem verdadeiramente ridículo, quando incapaz de socorrer a si

17 PLATÃO, Górgias, 486a-d.

18 PLATÃO, Górgias, 508d-e. 
mesmo? Porventura não seria aquele socorro que nos afasta do maior maleficio? Porém é absolutamente necessário que o socorro mais vergonhoso seja ser incapaz de socorrer a si mesmo ou a seus amigos e parentes, e o segundo mais vergonhoso, o relativo ao segundo mal, e o terceiro, o relativo ao terceiro mal, e assim por diante. Como cada mal possui por natureza uma magnitude, a beleza de ser capaz de se socorrer contra cada um deles lhe é proporcional, bem como a vergonha de não sê-lo. ${ }^{19}$

Designado um dos elementos essenciais que cercam toda a discussão em torno da função da arte retórica, pode-se distinguir um esforço especial para responder a seguinte questão: a morte deve ser evitada a qualquer custo? Evidencia-se assim a relevância da relação de Sócrates com a morte e a retórica, ou melhor, com um tipo de retórica ${ }^{20}$.

Dessa forma, se os sofistas representados por Górgias, Polo e Cálicles elevam o valor da arte retórica, eles o fazem devido à utilidade que ela parece ter para que o seu detentor possa se "auto resgatar" caso se encontre em algum situação de perigo, que seria em última análise, o perigo da morte. O valor associado à retórica provém, por essa perspectiva, de uma relação direta com o medo da morte. Desse modo, se Sócrates não teme a sua morte e não deseja evita-la a qualquer custo, ele se encontra em um lugar privilegiado em relação ao sofista, pois, nem se associa a retórica como uma arte imprescindível, como também pode utiliza-la sem por isso tornar-se injusto.

No trecho abaixo podemos observar uma passagem retirada do início do diálogo Górgias onde se evidencia a intenção de investigar, especificamente, o poder da arte de Górgias. Sócrates pergunta: “qual é o poder da arte do homem?”. Essa pergunta é respondida por Polo que a interpreta como se fosse "qual o poder da arte daquele homem?”. Nesse caso, para Polo, trata-se do poder da arte de um homem especifico que no caso, é Górgias.

SOC: Bem dito, Cálicles. Mas ele desejaria, porventura, dialogar conosco? Pois quero saber dele qual é o poder da arte do homem e o que ele promete e ensina; o resto da exibição, deixemos para outra ocasião, como dizes. (...) POL: Querefonte, as artes são abundantes entre os homens, descobertas da experiência experimentalmente. Pois a experiência faz com que nossa vida seja guiada pela arte, enquanto a inexperiência, pelo acaso. Diferentes homens participam de cada uma delas

19 PLATÃO, Górgias, 509a-c.

20 Ver: BRICKHOUSE; SMITH, The Myth of the Afterlife in Plato's Gorgias, 2007. 
de formas diferentes, e das melhores artes, os melhores homens. Dentre estes últimos, eia aqui Górgias, que participa da mais bela arte. (...) SOC: Com certeza. Mas ninguém está perguntando de que qualidade ela é, e sim que arte é essa, e por qual nome Górgias deve ser chamado. Assim como Querefonte te formulou as perguntas anteriores e tu lhe respondesse correta e brevemente, dize-me agora, de modo semelhante, que arte é essa e por qual nome devemos chamar Górgias! Ou melhor: dize-nos tu mesmo, Górgias, como devemos te chamar e de que arte tens conhecimento! GOR: Da retórica, Sócrates. ${ }^{21}$

A conversa acima se passa no seguinte contexto: Sócrates chega atrasado, junto com Querefonte e perde a majestosa exibição discursiva de Górgias. Cálicles o recebe com gracejos que transformam o atraso ocorrido análogo à chegada em uma guerra ou batalha. Imediatamente Sócrates entra no jogo iniciado por Cálicles e clama ter chegado, não depois da guerra, mas depois da festa ${ }^{22}$. Não é coincidência, como nada parece ser em Platão, que o diálogo se inicie sobre e entre os pilares de guerra e festa ${ }^{23}$.

Sócrates chega atrasado para a exibição bem sucedida do sofista, ele perde a festa, mas chega para iniciar sua própria festa, que também é uma batalha ${ }^{24}$. Sócrates perde a apresentação do estrangeiro que veio mostrar sua arte, mas, quando oferecida à oportunidade de participar de uma exibição privada de tamanho talento, Sócrates apresenta as regras do jogo. Ele não deseja uma exibição, um discurso. Antes disso, deseja uma conversa, um diálogo. E pergunta, exigindo uma resposta em seus próprios termos; qual o poder da arte do homem ${ }^{25}$ ?

Sabemos, através das personagens do diálogo, que Górgias afirma ser capaz de responder a qualquer pergunta, sobre qualquer assunto ${ }^{26}$. Porém, Sócrates interdita a forma pela qual Górgias discursa e assim, o diálogo segue para o conhecido terreno de questionamento socrático. Contudo, algo acontece, Polo coloca-se como, de certa forma, representante de Górgias, e Querefonte, de Sócrates. A pergunta que orienta a

\footnotetext{
21 PLATÃO, Górgias, 447b-449a.

22 PLATÃO, Górgias, 447a.

23 ARAÚJO, Da Arte, p. 13-14.

24 ARAÚJO, Da Arte, p. 14.

25 PLATÃO, Górgias, 447b-c.

26 PLATÃO, Górgias, $447 \mathrm{c}$-d.
} 
discussão permanece; qual o poder da arte de Górgias? Polo, sem embaraço, responde que Górgias detém as melhores das artes, por ser um dos melhores homens.

Nesse momento do diálogo evidencia-se algo que será fundamental para a compreensão desse estudo. A arrogância dos sofistas em relação à grandeza da arte retórica parece ser o ponto chave para a crítica socrática. Veremos adiante, como Sócrates reconhece certa utilidade da retórica, porém está em um lugar menos pretencioso, tal como, segundo o filósofo, lhe cabe.

A principal argumentação dos sofistas no diálogo Górgias sobre a arte retórica contorna e atravessa em diversos momentos a utilidade que a retórica tem que salvar vidas (a própria e a de amigos), principalmente no que concerte a uma defesa em tribunal, contra possivelmente uma acusação injusta. Assim, uma das principais funções da retórica, que, aliada a outras, a tornaria tão bela, é permitir que aquele que domina a arte resgate a si mesmo e a amigos de um grande perigo. Pode-se observar, na passagem a seguir, a explicitação da função da retórica na conversa entre Sócrates e Cálicles no diálogo Górgias.

SOC: Eu sei, bom Cálicles, amenos que eu seja surdo; pois já ouvi repetidamente tanto de ti quanto de Polo momentos atrás, e de quase todos os demais habitantes dessa cidade. Mas ouve também tu o que digo: se quiser, ele, um homem vicioso, matará um homem belo e bom. CAL: E isso não é motivo de fúria? SOC: Não para quem é inteligente, como indica o argumento. Ou julgas que o homem deve se dispor para o quanto mais viver, e praticar aquelas artes que sempre nos salvam dos perigos, tal como a retórica nos salva nos tribunais, a qual me ordenas praticar? CAL: Sim, por Zeus, e te aconselho corretamente. ${ }^{27}$

Pode-se observar que Cálicles incentiva Sócrates a se dedicar à retórica (durante o diálogo Cálicles vincula a filosofia a uma atividade infantil e exorta Sócrates a se dedicar à retórica) por essa ser a arte por excelência que pode salvá-lo dos perigos, principalmente daqueles vinculados aos tribunais. Porém, a partir desse momento, Sócrates coloca em questão a grandeza da retórica ao compará-la com outras artes que também salvam vidas, porém as fazem sem a arrogância e o senso de importância que os sofistas atribuem à retórica.

27 PLATÃO, Górgias, 511b-c. 
SOC: E então, excelente homem? Acaso o conhecimento da natação te parece ser um conhecimento solene? CAL: Não, por Zeus, não a mim. SOC: Não obstante, também ele salva os homens da morte, quando se defrontam com situações que exigem esse conhecimento. Mas se ele te parece ínfimo, vou te mencionar outro conhecimento de maior mérito, a arte da navegação, que salva dos perigos mais extremos não só as almas, como também os corpos e os bens, semelhante à retórica. Esse conhecimento é modesto e ordenado e não é solene porque realiza algo esplêndido; fazendo as mesmas coisas que a jurisprudência, ele cobraria dois óbolos, julgo eu, se nos trouxesse salvos de Egina para cá; se nos trouxesse salvos do Egito ou de Ponto, a cobrança seria, depois de atracar ao porto, de no máximo duas dracmas em troca desta grande benfeitoria: trazer a salvo o que há pouco mencionava, ou seja, a si mesmo, as crianças, os bens e as mulheres. Esse homem, detentor dessa arte e realizador dessas coisas, após o desembarque, caminha à margem do mar e de sua nau com aspecto moderado. (Platão. Górgias. 511c-e).

Sócrates apresenta a arte da navegação e da natação como outras artes que também salvam vidas, assim como a retórica. Ao fazer isso, ele coloca em igualdade tais artes. Ele aponta para o fato que, o piloto do barco, por exemplo, não percebe a si mesmo como alguém especial, possuidor de grandes poderes enquanto que os sofistas compreendem a como sendo a mais sublime das artes. Quando Sócrates assemelha a retórica a outras artes que salvam vidas, ele reconhece que existe de fato uma utilidade atribuída a ela e, por isso, sua crítica parece ser, na verdade, direcionada a grandeza que a arte em questão possui, a presunção dos sofistas, a manta púrpura de Górgias.

SOC: (...) Por isso, o piloto não costuma ser solene, ainda que nos traga salvos, tampouco o construtor militar, ó admirável homem, que tanto quanto o general ou qualquer outro além do piloto, é capaz de salvar-nos em certas ocasiões; pois ele salva, às vezes, cidades inteiras. O caso do jurisprudente não te parece semelhante? Aliás, se ele quisesse dizer, Cálicles, as mesmas coisas que dizeis vós, ele solenizaria o seu ofício e vos amortalharia com discursos e exortações de que deveis vos tornar construtores militares e que o resto de nada vale, pois o argumento lhe é suficiente. Mas tu o desprezas tanto quanto a sua arte, e o chamarias de construtor militar como se o censurasse, e não desejarias conceder a tua filha em casamento ao filho dele, tampouco tu aceitarias a sua filha. Ademais, segundo as razoes pelas quais elogias as tuas próprias coisas, com que argumento justo desprezas o construtor militar e todos os outros referidos há pouco? Sei que dirias que é melhor e de melhor progênie. Contudo, se o melhor não for o que eu afirmo que seja, e a virtude consistir em salvar a si mesmo e 
as suas propriedades, independentemente do tipo de homem que seja, tornar-se-á absolutamente ridículo o teu vitupério ao construtor militar, ao médico ou a qualquer outra arte que se realiza em vista de nossa salvação. Mas, homem virtuoso, observa se o nobre e o bem não se diferenciam de salvar e ser salvo. Pois o verdadeiro homem não deve se preocupar em viver o quanto tempo for nem se apegar à vida, mas, confiando essas coisas ao deus e acreditando nas mulheres quando dizem que ninguém escaparia a seu destino, ele deve se volver à seguinte investigação: de que modo alguém que vive por certo tempo viveria da melhor maneira possível? Acaso assemelhando-se a essa constituição política em que vive? Tu, portanto, deves agora te assemelhar ao povo de Atenas o quanto puderes, se pretende ter-lhe amizade e magnífico poder na cidade. Observa se isso é vantajoso a ti e a mim, para que não tenhamos, homem extraordinário, o mesmo sofrimento por que passam, segundo dizem, as mulheres da Tessália, as purificadoras da lua: a escolha desse poder na cidade será para nós a custo de no que é mais caro. Porém se julgas que um homem qualquer poderá te transmitir uma arte apta a te conferir magnífico poder nessa cidade sem que te assemelhes à sua constituição política, seja para melhor ou para pior, tu, como me parece, não deliberas corretamente, Cálicles. Pois não deves ser imitador, mas naturalmente semelhante a tais homens, se intentas criar uma amizade legítima com o povo de Atenas. ${ }^{28}$

A retórica parece ter uma utilidade reconhecida e, inclusive, em certa medida incorporada pela dialética socrática. Deve-se notar portando três elementos importantes. O primeiro: há um reconhecimento da utilidade da arte retórica. Segundo: há uma crítica em relação à arrogância sofística em função da arte retórica. Terceiro: há um reconhecimento que, a retórica, assim como a natação e a navegação, salva vidas sem questionar se as vidas em questão devem ser salvas ou não.

A questão parece ser comportamental; para Sócrates não está no escopo do retórico, assim como não está no escopo do piloto de barco ou do nadador, saber se as vidas em questão devem ou não ser salvas pela sua arte. A verdadeira pergunta que Sócrates propõe é: se a vida em questão é digna de ser salva ou não. Assim, ele retira a retórica de um pódio de grandeza em relação às outras artes e a realoca na categoria de artes que deveriam estar submetidas à outra arte arquitetônica, para usar um vocabulário aristotélico. Assim, a arte arquitetônica seria a responsável pela avaliação da vida que poderia ser salva ou não.

28 PLATÃO, Górgias, 512b-e. 
Desse modo, foi possível observar que, no diálogo Górgias, Sócrates não parece disposto a aceitar incondicionalmente a beleza, o poder e a grandeza da retórica, tampouco a sabedoria de Górgias. Ele coloca, através de seus elenkhoi, o valor da arte retórica em questão. Segundo Carolina Araújo, “Se Górgias queria entender o discurso como realizador de obras divinas, Sócrates quer saber que deus é esse, se ele é bom ou mau.”29. Uma das questões importantes no diálogo parece ser a interdição que Sócrates promove contra a grandeza absoluta da retórica. A retórica, de acordo com o que busquei defender, possui uma utilidade, tanto para a personagem Sócrates, quanto para o autor Platão, porém esta utilidade deveria ser submetida aos valores filosóficos. Acredito que exista um reconhecimento da utilidade da arte retórica, porém Sócrates transforma sua relação com ela na mesma medida em que transforma sua relação com a morte. Górgias, Polo e Cálicles parecem viver subordinados ao pathos do medo. O uso que fazem da retórica relaciona-se com o medo de serem acometidos por injustiça e isso os levaria, segundo a visão socrática, a cometer injustiça. Adotar totalmente a retórica proposta pelos sofistas seria tornar-se injusto, e isso seria impensável para aquele que, como Sócrates, vive sob o signo da virtude filosófica e não teme a morte. Ao não temer a morte, Sócrates pode adotar, com ressalvas, estratégias retóricas e ser verdadeiramente livre. Sócrates promove um rebaixamento do status da retórica, uma tentativa de despir Górgias de seu manto púrpura, ou seja, de mostrar que a presunção gorgiana da potência e da grandeza da retórica é uma ilusão.

29 ARAÚJO, Da Arte, p. 15. 


\section{REFERÊNCIAS BIBLIOGRÁFIGAS}

ARAÚJO, Carolina. Da Arte - Uma leitura do Górgias de Platão. Belo Horizonte: Editora UFMG. 2008.

BRICKHOUSE, T. C. ; SMITH, N. D. The Myth of the Afterlife in Plato's Gorgias. In: M. ERLER, M. ; BRISSON, L. (edi.). Gorgias - Menon: Selected Papers From the Seventh Symposium Platonicum. St. Augustin: Academia Verlag, 2007, 128-37.

HOLANDA, Luisa Severo Buarque de. Aquiles como exemplo e contraexemplo. Anais de Filosofia Clássica Online. Notas sobre o exemplo de Aquiles na Apologia de Sócrates (28c) e na República (386c-d e 516d): o filósofo, a retórica e a morte’), v.11, 2017, p. 46-65.

. Tragédia e antitragédia na Apologia de Sócrates: uma análise retórica. OQNFP, vol. 27, n. 41, 2018.

As promessas da retórica gorgiana: pleonexia e medo no Górgias de Platão. OQNFP, vol. 27, n. 42, 2018.

PLATÃO. Apologia de Sócrates/Críton. [Tradução Bilíngue de Carlos Alberto Nunes] Belém: Ed. UFPA, 2015.

PLATÃO. Górgias. [Tradução do grego, ensaio introdutório e notas de Daniel R.N Lopes]. São Paulo: Perspectiva, 2014.

PLATON. Platon - oeuvres complètes: Phèdre. [Luc Brisson]. Paris : Éditions Flammarion, 2008 et 2011.

MCCOY, Marina. Platão - A retórica de filósofos e Sofistas. São Paulo: Madras Editora LTDA, 2010. 